\title{
Knowledge Sharing is The Key Success Factor to Building Competitive Advantage in Indonesia: a Review and Hint for Future Research
}

\author{
Sarah Sentika1, Rivaldi Arissaputra ${ }^{2}$ \\ ${ }^{1,2}$ Department of International Trade, 'Aisyiyah University Bandung, Indonesia \\ sarahsentika@unisa-bandung.ac.id, rivaldi.arissaputra@unisa-bandung.ac.id
}

\begin{abstract}
Today's development of information and technology requires companies to focus on managing knowledge management, Knowledge Sharing. This is one of the drivers in the company's progress to can compete. This study aims to review and integrate the literature from several previous studies regarding Knowledge Sharing, which examines the implications of implementing knowledge sharing for companies and what things encourage people to share knowledge in Indonesia. This study conducted a narrative review of the literature using the Systematic Literature Review (SLR) method in Scopus indexed journals. 121 articles were selected with four filtering stages to produce 20 articles. The results of the study are: Knowledge Sharing can be applied in different fields; Research on Knowledge Sharing is subjective due to differences in work values and interactions with technology from time to time; Factors that influence Knowledge Sharing include motivation, learning, sharing opportunities, relationships, communication, trust, satisfaction, environmental culture, nature of knowledge, hard rewards, a pleasure to help others, soft rewards, and self-efficiency; and Knowledge Sharing can have a positive impact on the company.
\end{abstract}

Keywords

knowledge sharing; key success; competitive advantage

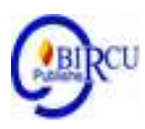

\section{Introduction}

Currently, information technology is developing very rapidly, and companies realize that intangible resources such as knowledge and the transfer process are the main factors in increasing the company's competitiveness compared to tangible resources (Zareie \& Navimipour, 2016). Continuously in a competitive and dynamic economy (Foss \& Pedersen, 2002). In today's competitive era, knowledge and intellectual asset management seem to be the best answer when a company wants to gain a competitive advantage (Ashouraie \& Navimipour, 2015). To achieve a competitive advantage, companies cannot rely solely on staff, but training systems that focus on selecting employees with specific knowledge, skills, abilities, or competencies, or helping employees acquire these skills (Brown \& Duguid, 1991). Companies should also consider how to transfer expertise and knowledge from the experts who will give it to the right person to receive it (Hinds, Patterson, \& Pfeffer, 2001). Knowledge management is a significant factor for companies that want to gain a competitive advantage. Knowledge management is a cognitive activity to identify, organize, and organize knowledge research (Al-Hawamdeh, 2003).

Among many research on knowledge management, knowledge sharing has been recognized as the primary focus that is strategically very important for companies because it allows one to receive the knowledge needed from knowledge owners to improve performance to become beneficial for the company (Wang \& Ko, 2012). As one of the 
crucial activities in knowledge, sharing knowledge is a basic where the knowledge had by employees in a company can contribute to the development of innovation for goal is to achieve the company's competitive advantage (Jackson, Chuang, Harden, \& Jiang, 2006). In the process, knowledge exchange can occur explicitly and implicitly (Hooff, Elving, Meeuwsen, \& Dumoulin, 2003). Sharing knowledge among employees allows companies to take advantage of knowledge-based resources themselves (Cabrera \& Cabrera, 2005).

Previous research has shown that knowledge sharing is applied in different countries and has different results in practice. The results of several previous research shown that knowledge sharing has a positive impact on reducing production costs, faster new product development work processes, increased team performance, increased company ability to innovate, and company performance, including growth in sales and revenue from products and services. (Arthur \& Huntley, 2005)(Collins \& Smith, 2006)(Cummings, 2004)(Hansen, 2002)(Lin, 2007)(Mesmer-Magnus \& DeChurch, 2009) Likewise in Indonesia, currently companies in Indonesia are susceptible to the development of information and technology. Of course, knowledge sharing is something that companies can't avoid considering how big the benefits are. Without effective knowledge-sharing activities, companies may not integrate the critical knowledge, skills, and innovation capabilities of experts to complete complex work (Zhang, De Pablos, \& Zhou, 2013). According to a survey of Fortune 500 companies, companies have lost as much as $\$ 31.5$ billion for their failure to implement good knowledge sharing (Babcock, 2004). Therefore, because the potential benefits realized from knowledge sharing are enormous, companies should invest a lot of time and money into knowledge management.

The purpose of this study is to review and integrate the literature from several previous studies on knowledge sharing, which examines the implications of implementing knowledge sharing for companies and what things encourage people to share knowledge in Indonesia.

\section{Review of Literature}

\section{Information, Knowledge, and Knowledge Sharing}

In research, management information systems tend to use knowledge to show value and uniqueness in examining knowledge management systems compared to traditional information systems (Alavi \& Leidner, 2001). The fact is that until now, researchers and experts have different opinions regarding information and knowledge. Some experts argue that all information is knowledge, while knowledge includes information and managing that knowledge (Kogut \& Zander, 1992)(Zander \& Kogut, 1995). However, (Nonaka, 1994) has another opinion that his information is only a "message flow" nothing more than that, while knowledge is based on information that is justified by one's beliefs. According to (Bartol \& Srivastava, 2002), there is no difference in the specifics in practice between information and knowledge in sharing knowledge. From the various opinions above, knowledge can be said as information that goes through a justification process from someone. Knowledge sharing is all activities related to providing task information and knowledge to help and collaborate with others to solve problems, develop new ideas, or implement policies or procedures (Dorsey, 2003). Knowledge sharing done in writing or through direct face-to-face communication with experts, or documenting, organizing and capturing knowledge for others (Dorsey, 2003). 


\section{Research Methods}

This study conducts a narrative review of the literature that describes the impact of implementing knowledge sharing. The Systematic Literature Review (SLR) method used in this study, an organized method to find, collect, and evaluate a collection of literature on a particular topic. In this study, SLR used to conduct a comprehensive study of the impact of knowledge sharing in various ways. Then, the validity of the study selection procedure evaluated by describing the search process, including the article selection and classification process from the online database as follows:

\section{URL database}

Scopus https://www.scopus.com

Table 1. Article Selection Table "Knowledge Sharing"

\begin{tabular}{|c|c|c|}
\hline Selection Stage & Number of Articles & Filter \\
\hline 1 & 121 & Location: Indonesia \\
\hline 2 & 65 & Years: 2018, 2017 and 2016 \\
\hline 3 & 34 & Document type: Article \\
\hline 4 & 20 & Field of Science: Business and Social Sciences \\
\hline
\end{tabular}

Table 2. The distribution of articles used as references based on the online database https://www.scopus.com is as follows:

\begin{tabular}{|c|c|c|}
\hline Year & Writer & Journal Name \\
\hline 2017 & $\begin{array}{l}\text { Rumanti, AA, Samadhi, } \\
\text { Wiratmadja, II, Sunaryo, I. }\end{array}$ & $\begin{array}{l}\text { International Conference on Industrial } \\
\text { Engineering and Engineering Management }\end{array}$ \\
\hline 2017 & $\begin{array}{l}\text { Saide, Trialih, R., Wei, H.-L., Okfalisa, } \\
\text { Anugrah, W. }\end{array}$ & International Journal of Business and Society \\
\hline 2017 & Supartha, WG, Dewi Kumala Ratih, IA & $\begin{array}{l}\text { Journal of Business and Retail Management } \\
\text { Research }\end{array}$ \\
\hline 2017 & $\begin{array}{l}\text { Tesavrita, C., Suryadi, K., Wiratmadja, II, } \\
\text { Govindaraju, R. (2017) }\end{array}$ & $\begin{array}{lll}\text { International Conference on Industrial } \\
\text { Engineering and Applications }\end{array}$ \\
\hline 2017 & $\begin{array}{l}\text { Rumanti, AA, Samadhi, } \\
\text { Wiratmadja, II, Reynaldo, R. }\end{array}$ & $\begin{array}{lcc}\text { International Conference } & \text { on } & \text { Industrial } \\
\text { Engineering and Applications } & & \\
\end{array}$ \\
\hline 2017 & $\begin{array}{l}\text { Noprisson, H., Zulkarnaim, N., Hidayat, E., } \\
\text { Firman, R., Putra, ED, Cahyaningsih, E., } \\
\text { Sensuse, DI }\end{array}$ & $\begin{array}{l}\text { International Conference on Information } \\
\text { Technology Systems and Innovation }\end{array}$ \\
\hline 2017 & $\begin{array}{l}\text { Sihombing, IHH, Supartha, IWG, Subudi, } \\
\text { M., Dewi, IGAM }\end{array}$ & Global Business and Finance Review \\
\hline 2017 & Wulandari, F., Djastuti, I., Nuryakin & ean Research Studies Journal \\
\hline 2017 & $\begin{array}{l}\text { Fauzia, S., Budiningsih, I., Djaelani, A., } \\
\text { Ahmad, M. }\end{array}$ & Polish Journal of Management Studies \\
\hline 2016 & $\begin{array}{l}\text { Kurniawati, A., Arisamadhi, TMA, } \\
\text { Wiratmadja, II }\end{array}$ & $\begin{array}{l}\text { International Conference on Industrial } \\
\text { Engineering and Engineering Management }\end{array}$ \\
\hline 2016 & Ramadhan, F., Samadhi, TMAA & $\begin{array}{l}\text { International Conference on Industrial } \\
\text { Engineering and Engineering Management }\end{array}$ \\
\hline 2016 & $\begin{array}{l}\text { Rumanti, AA, Ari Samadhi, TMA, } \\
\text { Wiratmadja, II }\end{array}$ & $\begin{array}{l}\text { International Conference on Industrial } \\
\text { Engineering and Engineering Management }\end{array}$ \\
\hline 2016 & Tesavrita, C., Suryadi, K., Wiratmadja, II & $\begin{array}{l}\text { International Conference on Industrial } \\
\text { Engineering and Engineering Management }\end{array}$ \\
\hline
\end{tabular}




\section{Results and Discussion}

Research in SMEs conducted by (A A Rumanti, Samadhi, Wiratmadja, \& Sunaryo, 2017) shows that knowledge sharing is one of the main components and is an essential parameter for creating open innovation. Knowledge sharing is influenced by motivation, learning, opportunities to share, relationships, communication, trust and satisfaction, environmental culture, and the nature of knowledge.

Research in education conducted by (Trialih, Wei, \& Anugrah, 2017) investigates the factors influencing knowledge sharing among academic institution workers. This study seeks to fill the gaps in the current literature by assessing the factors that influence knowledge sharing among employees in educational institutions. This study indicates that hard rewards, communication skills, a pleasure to help others, and soft rewards influence knowledge sharing behavior, which also influences the quality of knowledge sharing. In addition, communication skills are the most contributing factor in knowledge sharing.

Research in the Small Crafts Industry was conducted by (Supartha \& Ratih, 2017), which showed first, there is a pattern of relationship between knowledge sharing and absorptive capacity, in its dimensions (a) knowledge distribution and (b) knowledge gathering has a positive and positive impact. Significant effect on absorptive capacity. Second, the impact of creative leadership on knowledge sharing shows that visionary leadership has a positive and significant impact on knowledge sharing. However, the greater role of innovative capacity in influencing knowledge sharing implies an imbalance between constructs, which is indicated by leaders' lack of attention to employees' needs.

Research in the SME sector was also carried out by (Ceicalia Tesavrita, Suryadi, Wiratmadja, \& Govindaraju, 2017), resulting in a comparative framework between the dairy cow SME group in Bandung and the Batik SME group in Surkarta as follows:

\begin{tabular}{|c|c|c|c|c|}
\hline Dimension & \multicolumn{2}{|r|}{ SME Cluster 1} & \multicolumn{2}{|r|}{ SME Cluster 2} \\
\hline $\begin{array}{l}\text { Product and } \\
\text { Characteristic }\end{array}$ & \multicolumn{2}{|c|}{$\begin{array}{c}\text { SME cluster produce dairy product, consist of } 7000 \text { SME, } \\
\text { and located di West Java, Indonesia. } \\
\text { This cluster already has organizational stucture with a } \\
\text { clear procedure and job description. } \\
\text { Each SME focus on production process and product } \\
\text { quality, while marketing, sales, and organization } \\
\text { development was handle by organization. }\end{array}$} & \multicolumn{2}{|c|}{$\begin{array}{l}\text { SME that produced batik and clothes from batik. Consists } \\
\text { of } 80 \text { SME and located in Central Java, Indonesia. } \\
\text { Those SME were managed by an organization called } \\
\text { Kampoeng Batik Laweyan Development Forum that } \\
\text { facilitate collaboration between SME and external } \\
\text { organization. } \\
\text { Each SME done its own production, product } \\
\text { development, marketing, and sales. }\end{array}$} \\
\hline \multirow{3}{*}{$\begin{array}{l}\text { Partner dan } \\
\text { Collaboration } \\
\text { output }\end{array}$} & Government & $\begin{array}{l}\text { Colaboration to develop community } \\
\text { economy and sales }\end{array}$ & Government & $\begin{array}{l}\text { Collaboration in developing tourism } \\
\text { based on culture and batik product }\end{array}$ \\
\hline & Academician & $\begin{array}{l}\text { Collaboration in increasing production } \\
\text { capacity and waste handling. }\end{array}$ & Academician & $\begin{array}{l}\text { Collaboration in incresing product } \\
\text { quality and minimizing waste }\end{array}$ \\
\hline & Customer & Collaboration in product development & NGOs & $\begin{array}{l}\text { Collaboration in funding and } \\
\text { community development }\end{array}$ \\
\hline Mechanism & \multicolumn{2}{|r|}{ Long-term collaboration } & \multicolumn{2}{|c|}{ Long-term collaboration } \\
\hline $\begin{array}{l}\text { Inter- } \\
\text { organizational } \\
\text { knowledge sharing }\end{array}$ & \multicolumn{2}{|c|}{$\begin{array}{l}\text { Knowledge sharing was done through training and } \\
\text { discussion. Collaboration prosess was done by several } \\
\text { individu as a group leader. Knowledge that was shared in } \\
\text { those forum that diseminated throug out the group by each } \\
\text { leader. }\end{array}$} & \multicolumn{2}{|c|}{$\begin{array}{l}\text { Knowledge sharing was done both offline and online } \\
\text { through training, discussion, researeh and internship. }\end{array}$} \\
\hline $\begin{array}{l}\text { Intra- } \\
\text { organizational } \\
\text { knowledge sharing }\end{array}$ & \multicolumn{2}{|c|}{$\begin{array}{l}\text { Knowledge sharing within organization was done offline } \\
\text { through discusition group. }\end{array}$} & \multicolumn{2}{|c|}{$\begin{array}{l}\text { Knowledge sharing within organization was done oftline } \\
\text { through discusiion group. }\end{array}$} \\
\hline
\end{tabular}


Still in the same research field, namely UKM (Augustina Asih Rumanti, Samadhi, Wiratmadja, \& Reynaldo, 2017), conducting knowledge-sharing research on green innovation. The results show that knowledge sharing is one of the essential components of open innovation explained in this study that knowledge sharing is an idea in an organizational context. Innovation will occur through the availability of new knowledge that is exchanged through knowledge transfer among company members. The factors that influence knowledge sharing are motivation, relationships, environmental culture, learning, sharing opportunities, nature of knowledge, communication.

Research in the field of education conducted by (Noprisson et al., 2016) resulted in various factors influencing the sharing of tacit knowledge and sharing of explicit knowledge. For example, a shared vision has no significant effect on direct knowledge sharing, and trust affects explicit knowledge sharing. It also shows that the influence of the social factor component between tacit knowledge sharing and explicit knowledge sharing is different. The elements of social capital that affect the sharing of detailed knowledge are the shared language, bonds of social interaction, reciprocal norms, identification, and trust. However, the components of social capital that affect explicit knowledge sharing are identification, standard criteria, bonds of social interaction, shared language and shared vision. In addition, implicit knowledge sharing more influenced by human capital than explicit knowledge sharing. Sharing tacit knowledge and detailed knowledge also have different impacts on building students' human resources. The results show that sharing tacit knowledge greatly influences students' human resources. This means that discussions or teamwork preferable to advancing students' human capital rather than simply sharing documents.

The research in the hospitality industry conducted by (Sihombing, Supartha, Subudi, \& Dewi, 2017) shows that work motivation doesn't have positive relation significantly to organizational commitment and knowledge. Sharing behavior and organizational commitment have a fully mediating role in the relationship between job satisfaction and behavior sharing knowledge. This study also says that knowledge-sharing behavior should be further increased to avoid service delivery failures and reduce operational costs.

Research in the business field conducted by (Wulandari \& Djastuti, 2017) found a significant effect between trust and knowledge sharing. Another finding was that knowledge sharing would have a more substantial impact if employees trusted the person doing the knowledge transfer. This study also provides evidence that knowledge sharing significantly affects business performance.

Research in the property industry conducted by (Fauzia, Budiningsih, Djaelani, \& Ahmad, 2017) shows a 'positive', 'strong', and significant correlation between organizational learning, knowledge sharing, and organizational commitment simultaneously to team member innovative behavior. This means organizational learning, knowledge sharing, and commitment simultaneously affect team members' creative behavior.

Research in the context of generational differences was conducted by (Kurniawati, Arisamadhi, \& Wiratmadja, 2016). This study examines the relationship between individual factors, knowledge sharing, and individual work performance. The relation is explored in different generations, namely baby boomers, generation X, and generation Y. The results of the research are as follows: 
The relationship between individual factors, knowledge sharing, and job performance is different in each generation. The difference can be seen due to differences in the value of work and interaction with technology. The questionnaire results show the relationship between the characteristics of knowledge recipients, online knowledge sharing, and individual work performance. It happens because the respondents are company employees who actively use online knowledge management systems.

\begin{tabular}{|c|c|c|c|c|c|c|}
\hline & \multicolumn{2}{|c|}{ Baby Boomers } & \multicolumn{2}{|c|}{ Generation $\mathrm{X}$} & \multicolumn{2}{|c|}{ Generation $\mathrm{Y}$} \\
\hline & Percentage & Scale & Percentage & Scale & Percentage & Scale \\
\hline $\begin{array}{l}\text { Knowledge Provider } \\
\text { Characteristics }\end{array}$ & $66.67 \%$ & agree & $71.43 \%$ & agree & $52.22 \%$ & $\begin{array}{c}\text { strongly } \\
\text { agree }\end{array}$ \\
\hline $\begin{array}{l}\text { Knowledge Receiver } \\
\text { Characteristics }\end{array}$ & $57.14 \%$ & agree & $69.39 \%$ & agree & $51.43 \%$ & $\begin{array}{c}\text { strongly } \\
\text { agree }\end{array}$ \\
\hline $\begin{array}{l}\text { Online Knowledge } \\
\text { Sharing }\end{array}$ & $66.67 \%$ & agree & $80.36 \%$ & agree & $55.83 \%$ & agree \\
\hline $\begin{array}{l}\text { Offline Knowledge } \\
\text { Sharing }\end{array}$ & $62.50 \%$ & disagree & $66.07 \%$ & agree & $65.83 \%$ & agree \\
\hline $\begin{array}{l}\text { Individual Work } \\
\text { Performance }\end{array}$ & $83.33 \%$ & $\begin{array}{l}\text { strongly } \\
\text { agree }\end{array}$ & $80.95 \%$ & agree & $63.33 \%$ & agree \\
\hline
\end{tabular}

Research conducted in the automotive industry by (Ramadhan \& Samadhi, 2016) explains that the relationship between manufacturers and suppliers in the automotive industry involves a knowledge-sharing process. Knowledge sharing is a necessary process that can improve the performance of manufacturers and suppliers. Trust reflects the degree of cooperation and competitive relationship between supply chain members. Trust is facilitating strategic business interactions and knowledge sharing among independent companies. Inter-organizational trust influences participation, communication, influence strategy, opportunistic behavior, and inter-personal factors (expertise and attractiveness). This trust is what makes someone share knowledge.

Still, in the same research field, UKM (Augustina Asih Rumanti, Samadhi, \& Wiratmadja, 2016) show that the indicator that has the most significant influence on tacit knowledge is personal and community interaction explicit knowledge most potent effect is community. It is also known that there is an impact of tacit knowledge and detailed knowledge in SMEs on knowledge sharing. In contrast, the results of this study indicate that tacit knowledge and explicit knowledge have a significant impact on knowledge sharing. It means that implicit and explicit knowledge changes can affect knowledge sharing in SMEs.

Research conducted in the education industry by (C Tesavrita, Suryadi, \& Wiratmadja, 2016), shows that people with high self-efficacy are more willing to share their knowledge with others. This study uses a new approach in measuring the effect of technological aspects on knowledge sharing in online knowledge sharing systems, namely through usability theory, and finds that the usefulness of online knowledge sharing systems has a significant effect on knowledge sharing. This study proves that users' self-efficacy significantly influences how they perceive online knowledge-sharing systems. 


\section{Conclusion}

The conclusions that can find from the above study are:

1. Knowledge sharing can be applied in various fields such as SMEs, small creative industries, automotive, education, business, research, property, hospitality, etc.

2. Research on knowledge sharing is subjective due to differences in work values and interactions with technology over time.

3. Factors that influence knowledge sharing include motivation, learning, sharing opportunities, relationships, communication, trust, satisfaction, environmental culture, nature of knowledge, hard rewards, a pleasure to help others, soft tips, and self-efficiency.

4. Knowledge sharing can positively impact the company, among the effects of sharing knowledge, among others, creating innovation, improving the quality of employees, building creative leadership, improving employee performance, improving service quality, reducing costs, and improving business performance.

\section{References}

Alavi, M., \& Leidner, DE (2001). Review: Knowledge management and knowledge management systems: Conceptual foundations and research issues. MIS Quarterly, 25(1), 107-136.

Al-Hawamdeh, S. (2003). Knowledge management: Cultivating knowledge professionals. Elsevier.

Arthur, JB, \& Huntley, CL (2005). Lean up the organizational learning curve: Assessing the impact of deliberate learning on organizational performance under gainsharing. Academy of Management Journal, 48(6), 1159-1170.

Ashouraie, M., \& Jafari Navimipour, N. (2015). Priority-based task scheduling on heterogeneous resources in the Expert Cloud. Kybernetes, 44(10), 1455e1471.

Babcock, P. (2004). Shedding light on knowledge management. HR Magazine, 49(5), $46-50$.

Bartol, KM, \& Srivastava, A. (2002). Encouraging knowledge sharing: The role of organizational rewards systems. Journal of Leadership and Organization Studies, 9(1), 64-76.

Brown, JS, \& Duguid, P. (1991). Organizational learning and communities-of-practice: Toward a unified view of working, learning, and innovation. Organization Science. 40-57.

Cabrera, EF, \& Cabrera, A. (2005). Fostering knowledge sharing through people management practices. International Journal of Human Resource Management. 720-735.

Collins, CJ, \& Smith, KG (2006). Knowledge exchange and combination: The role of human resource practices in the performance of high-technology firms. Academy of Management Journal, 49(3), 544-560.

Cummings, JN (2004). Work groups, structural diversity, and knowledge sharing in a global organization. Management Science. 352-364.

Fauzia, S., Budiningsih, I., Djaelani, A., Ahmad, M. (2017). Dominant factors affect the behavior of innovative employees. Polish Journal of Management Studies. 2-40.

Foss, NJ, \& Pedersen, T. (2002). Transferring knowledge in MNCs: The role of sources of subsidiary knowledge and organizational context. Journal of International. Management. 49-67. 
Hansen, MT (2002). Knowledge network: Explaining effective knowledge sharing in multiunit companies. Organization Science. 232-248.

Hinds, PJ, Patterson, M., \& Pfeffer, J. (2001). Bothered by abstraction: The effect of expertise on knowledge transfer and subsequent novice performance. Journal of Applied Psychology. 1232-1243.

Jackson, SE, Chuang, C.-H., Harden, EE, Jiang, Y., \& Joseph, JM (2006). Toward developing human resource management systems for knowledge-intensive teamwork. In JM Joseph (Ed.), Research in personnel and human resources management, Vol. 25. (pp. 27-70). Amsterdam: JAI.

Kogut, B., \& Zander, U. (1992). Knowledge of the firm, combinative capabilities, and the replication of technology. Organization Science. 383-397.

Kurniawati, A., Arisamadhi, TMA, Wiratmadja, II (2016). Relationship among individual factors, knowledge sharing, and work performance: A model from baby boomers, generation $\mathrm{X}$, and generation $\mathrm{y}$ perspective. IEEE International Conference on Industrial Engineering and Engineering Management. 6-10.

Lin, H.-F. (2007d). Knowledge sharing and firm innovation capability: An empirical study. International Journal of Manpower, 28(3/4), 315-332.

Mesmer-Magnus, JR, \& DeChurch, LA (2009). Information sharing and team performance: A meta-analysis. Journal of Applied Psychology, 94, 535-546.

Nonaka, I. (1994). A dynamic theory of organizational knowledge creation. Organization Science, 5(1), 14-37.

Noprisson, H., Zulkarnaim, N., Hidayat, E., Firman, R., Putra, ED, Cahyaningsih, E., Sensuse, DI (2017). Influencing factors of knowledge sharing among students in Indonesia higher educational institutions. International Conference on Information Technology Systems and Innovation

Pulakos, ED, Dorsey, DW, \& Borman, WC (2003). Hiring for knowledge-based competition. In SE Jackson, MA Hitt \& AS Denisi (Eds.), Managing knowledge for sustained competitive advantage: Designing strategies for effective human resource management (pp. 155-176). San Francisco: Jossey-Bass.

Ramadhan, F., Samadhi, TMAA (2016) Inter-organizational trust and knowledge sharing model between manufacturer and supplier in the automotive industry. IEEE International Conference on Industrial Engineering and Engineering Management. 856-860.

Rumanti, AA, Ari Samadhi, TMA, Wiratmadja, II (2016). Impact of tacit and explicit knowledge on knowledge sharing at Indonesian Small and Medium Enterprise. IEEE International Conference on Industrial Engineering and Engineering Management. $11-15$.

Rumanti, AA, Samadhi, TMAA, Wiratmadja, II, Reynaldo, R. (2017). Conceptual model of green innovation toward knowledge sharing and open innovation in Indonesian SME. 4th International Conference on Industrial Engineering and Applications. 182186.

Rumanti, AA, Samadhi, TMAA, Wiratmadja, II, Sunaryo, I. (2018). Relationship among knowledge sharing, open innovation and green production: A multiple stakeholder perspective in batik industries. IEEE International Conference on Industrial Engineering and Engineering Management. 176-180. 2017 IEEE.

Saide, Trialih, R., Wei, H.-L., Okfalisa, Anugrah, W. (2017). Knowledge sharing behavior and quality among workers of academic institutions in Indonesia. International Journal of Business and Society. 353-368. 
Sihombing, IHH, Supartha, IWG, Subudi, M., Dewi, IGAM (2017). The role of organizational commitment mediating job satisfaction and work motivation with knowledge-sharing behavior in 4 star hotels in Badung regency, Bali. Global Business and Finance Review. 61-76.

Supartha, WG, Dewi Kumala Ratih, IA (2017). Antecedents of absorptive capacity: A proof of proposition. Journal of Business and Retail Management Research. 90-107.

Tesavrita, C., Suryadi, K., Wiratmadja, II (2016). Web usability and self-efficacy in promoting individual Knowledge Sharing. IEEE International Conference on Industrial Engineering and Engineering Management.16-20.

Tesavrita, C., Suryadi, K., Wiratmadja, II, Govindaraju, R. (2017). Intra-organizational and inter-organizational knowledge sharing in collaborative learning process: A conceptual framework for SME. 4th International Conference on Industrial Engineering and Applications. 187-191.

Van Den Hoof, B., Elving, W., Meeuwsen, J., \& Dumoulin, C. (2003). Knowledge sharing in knowledge communities and technologies. Deventer: Kluwer Academic Publisher.

Wang, W.-T., \& Ko, N.-Y. (2012). Knowledge sharing practices of project teams when encountering changes in project scope: a contingency approach. Journal of Information Science, 38(5), 423e441.

Wulandari, F., Djastuti, I., Nuryakin. (2017) Reassessment of the entrepreneurial motivation among female business owners to enhance SMES business performance in Indonesia. European Research Studies Journal. 18-34.

Zander, U., \& Kogut, B. (1995). Knowledge and the speed of the transfer and imitation of organizational capabilities: An empirical test. Organization Science, 6(1), 76-92.

Zareie, B. \& Navimipour, NJ (2016). The impact of electronic environmental knowledge on the environmental behaviors of people. Computers in Human Behavior, 59, 1e8.

Zhang, X., De Pablos, P.O., \& Zhou, Z. (2013). Effect of knowledge sharing visibility on incentive-based relationships in Electronic Knowledge Management Systems: an empirical investigation. Computers in Human Behavior, 29(2), 307e313. 